\title{
Canon, Jubilees 23 and Psalm 90
}

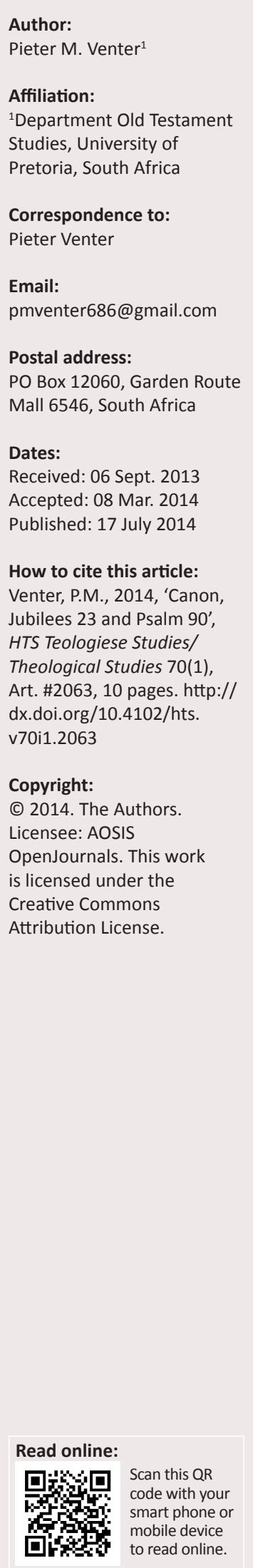

There never existed only one form of the biblical canon. This can be seen in the versions as well as editions of the Hebrew and Greek Bibles. History and circumstances played a central role in the gradual growth of eventually different forms of the biblical canon. This process can be studied using the discipline of intertextuality. There always was a movement from traditum to traditio in the growth of these variant forms of biblical canon. This can be seen in an analysis of the intertextuality in Jubilees 23:8-32. The available canon of the day was interpreted there, not according to a specific demarcated volume of canonical scriptures, but in line with the theology presented in those materials, especially that of Psalm 90.

\section{Introduction}

The concept of canon has two aspects: form and status. ${ }^{1}$ When status is only applied to a fixed final form of the biblical canon and not to the contents of a canon as well, it creates many problems. The final form is no longer used as a mere hermeneutic frame for reading the contents of the canon, but becomes a theological principle on its own. One then refers to 'the' canon forgetting that different forms of biblical canon exist. This study shows that many forms of the Christian canon exist.

Attention is next paid to the problem of reading a canon when status is not primarily linked to its form, but mainly to its contents. A study of the formation of an eventual canon of Christian scriptures indicates that the contents already had canonical status long before they reached any final and fixed form. In the dynamic growth of an eventual canon the phenomenon of intertextuality played a leading role. This article proposes that intertextuality should be used as a hermeneutical principle when reading existing scriptures as canon. Jubilees 23 is used to indicate how existing forms of canon were utilised to interpret scriptures in the past.

\section{One original canon?}

There was a time in textual criticism when conjectural emendation of apparent corrupt readings of the Hebrew text was the order of the day. The basic assumption at the back of this eclectic custom was that there initially was only one original text from which all other 'contaminated emanations' (cf. Talmon 2010b:418) originated.

Davies (1995:65) referred to an '[e]xtreme veneration for "canon", which is currently, pervasive in confessional studies'. ${ }^{2}$ Although historical criticism is usually rejected in these circles, a mutual concern with origins can be found here. Davies (1995) pointed out that historical criticism has expended its energies:

on examining the origins of the contents of bibles, getting drawn into a debate in which theological agendas run free. The origins of the biblical literature, as anyone who follows scholarly and popular discussions will recognize, is a matter of intense interest because of the importance these questions hold for some people's religious beliefs. (p. 70)

An extreme position is held by many people in Islam that the Qur'an is a celestial book dictated from heaven. In Christian circles John Wyclif thought that scripture was something conceived in the mind of God before creation. 'Because it was a divine idea, every word of it was true and every part as authoritative as the other' (Thomassen 2010:26). Although very few Christians see scripture in this extreme way today, the view was held by many, and is still held, that the Bible as the Word of God is independent of any human history. It was provided right from the start in the form we know it today. In Protestant circles acknowledgement is found of the human aspect of the Bible and the role tradition played in eventually creating a scriptural canon. However, the

1.Form refers to 'the official corpus of books accepted as scripture' (Uirich 2002:29). Status refers to a rule of faith.

2.Ulrich (2002:21) ascribed the present interest in the canon largely to the discovery of the Dead Sea Scrolls. 
divine source of the Bible is equally held in veneration. 'John Calvin regarded the Bible in its entirety as divinely inspired, a unique book in which every word was equally dictated by the Holy Spirit' (Thomassen 2010:26). However, Calvin recognised the human aspect by studying the Bible using a grammatical-historical method.

The difference between Christian groups regarding their views on the Bible as canon ${ }^{3}$ depends on the pro-rata weight each group gives to the divine-human relationship. The more the divine aspect is accentuated the more conservative the group is, minimising as far as possible the human aspect and the gradual growth of scriptures. ${ }^{4}$ When the human aspect is overrated a liberal view is held, neglecting the divine aspect. ${ }^{5}$

\section{Different canons}

It is no longer viable to speak of 'the' canon or 'the' Bible, intending one original canon. This statement can be illustrated by a simple investigation into the extent of the different canon collections and the different Christian versions. ${ }^{6}$ The Catholic, Protestant, Ethiopic, Orthodox (Greek and Russian), Coptic and Syrian canons differ with regard to extent and order, especially in the Old Testament section.

For instance, the English Revised Standard Version (RSV), ${ }^{7}$ containing the full Protestant Bible, was published in 1952. An expanded edition was published in 1977. Following the Septuagint the Apocrypha were incorporated this time. In this expanded version the three additions to Daniel in the Greek Septuagint were also included. Esther was not translated from Hebrew but from the Greek to indicate those parts that were added to the Hebrew text in the Greek Septuagint. These additions are also found in the Catholic editions of 1956 and 2006. They are in agreement with the

3.Ulirich (2002:34) indicated that the term 'canon', which is used by Christianity and Judaism, existed only since the 3rd century CE. It indicates 'the definitive, closed list Juf the books that constitute the authentic contents of scripture' (Ulrich 2002:340). of the books that constitute the authentic contents of scripture' (Ulrich 2002:340). process or with simply books that are canonical, because books can be, and were, process or with simply books that are canonical, because books can be, and
canonical ... long before there was a canon of scripture' (Ulrich 2002:34).

4.Aichele (2010:61-62) remarked that ' $[m]$ any Christians believe that the canonical texts possess some intrinsic quality that identifies them (and them alone) as the authoritative word of God. According to this view, the books of the Bible have been imbued with this quality either by God, their spiritual author, through inspiration of the historical human writers, or else by the church, which authorized the books by accepting them into the canon, again with the aid of divine inspiration. God has put his self-evident mark upon the Bible, and the text manifests its own divine origin."

5.Where the Bible is rather seen as a classic, the texts are understood 'as fallible ideas that have survived in the specific contingent histories of human beings' (Aichele 2010:62). The texts are then demythologised, but understood as still retaining and valuing truths that have withstood the test of time (cf. Aichele 2010:63).

6.Davies (1995:74) argued that a Bible exists as a single volume and it should therefore be read holistic as a whole. The specific order and contents of a Bible affects the literary reading of that Bible. The extent of a biblical canon produces a hermeneutic literary reading of that Bible. The extent of a biblical canon produces a hermeneutic
frame for the reading of that specific canon. Davies (1995:72) remarked 'I would not be able to read the NRSV holistically in the same way as its predecessor, the RSV because in that crucial gap between the Old and the New Testaments lies a series of writings that need to be integrated into the overall sequence.' It is therefore clear to him that "no appeal can be made to any normative "canonical" or "final form" (Davies 1995:74). Lundhaug (2010:69) remarked: 'The intertextual juxtaposition of the sanctioned texts creates a canonical metatext which may be seen to function as a commentary upon, and thus also in one sense as a replacement for the individual texts as such

7.Being an essentially literal translation the RSV stands in the stream of Tynndale's New Testament (1526), the King James Version (KJV 1611), the English Revised Version (RV 1885), the American Standard Version (ASV 1901 of which the RSV is an authorized revision) and the English Standard Version (2001, a revision of the 1971 edition of the Revised Standard Version). The literal translation with its word-forword correspondence reflects a view of canon which emphasises the divine aspect word correspondence reflects a view of canon which
and the idea of one original Hebrew and Greek text. fuller extent in Roman Catholic Bibles. The RSV translated a Hebrew text of the Old Testament with its 24 books, but arranged them in a different order (that of the Septuagint and Vulgate).

The New Revised Standard Version (NRSV) (1989) appeared in three main formats: one edition includes only the books of the Protestant canon; a second Roman Catholic Edition has all the books of the Roman Catholic canon, and The Common Bible, which includes all the books that appear in Protestant, Roman Catholic and Orthodox canons. The NRSV as translation is intended to serve devotional, liturgical and scholarly needs of the widest possible range of religious adherents. Davies (1995:66) remarks that the NRSV 'does not contain anyone's canon, but is a mixture of Jewish, Catholic and Protestant ones.'

This diversity of what canon entails, is expanded even more in the digital era. The emergence of humanism during the 15th-16th century and the invention of the printing press eventually brought the decision of what canon entails into the hands of the individual. Initially intended to be a mechanism to secure Christian ideology of the understanding of the scriptures against heretics, Jews, and other opponents of the Christian community, the publication of the Bible fell more and more into the hands of publishers and those who decided what should be included and what not. As literacy became common, the authority of the text shifted to the individual and his or her personal choice, ${ }^{8}$ what to read and what to believe (cf. Aichele 2010:53). This is advanced even more with the digitalisation of texts. It is now possible for everyone to compile, reproduce, or distribute texts. The fluidity of the text removes the constraints of printed matter. Aichele (2010) remarks:

The fixity of the individual text disappears, and the boundaries of the canon as a whole become permeable, for entire books can be effortlessly added to the directory of files or deleted from it. (p. 54)

This enhances the variety in biblical canons. Aichele (2010:5455) even goes so far as to declare that the 'decomposition and re-composition of the canon made possible and perhaps inevitable in electronic culture may lead to the disappearance once and for all of any canon.'

This new technology therefore threatens the whole idea of canon as one final compilation of books, authorised by some ecclesiastical establishment. The reader is now in full control of what she or he reads and believes.

It is therefore clear that it is not viable any longer to speak of 'the Bible' or 'the canon' without keeping this variety in mind. If there is only one canon, whose canon would it be? The decisions of people like translators, church councils and publishers played an immense role in the forming and tradition of these different biblical canons. In fact, it is not

8.A personal canon is also formed by ignoring certain sections of the Bible and giving preference to those that fit one's theology. This is a type of canon within the canon The chosen canon within the canon is used as norm to decide the weight a particular text carries (cf. Lundhaug 2010:70). 
totally wrong to state that canons are human artefacts. To use and understand this variety in canons we need to know the history behind them in which different people in so many ways played a decisive role (cf. Davies 1995:69).

The Protestant romantic idea held by many that only one original canon was received and handed down by the Reformation, cannot be sustained. The Reformation ${ }^{9}$ created a hybrid canon that never existed before. Next to the Septuagint and Vulgate it created a new canon. The contents of the New Testament they used, was in full agreement with the other two. However, for the Old Testament they used the available Hebrew manuscripts of the TaNaK and left out the so-called 'Apocrypha' found in the Septuagint and Vulgate. The books of the TaNaK (Old Testament) are arranged in a totally different order than the Septuagint and the Vulgate. The order in the Hebrew TaNaK is that of Law-WritingsProphets. The Septuagint and Vulgate order, still used in all present day versions, is that of Law-Early Prophets- WritingsProphets. This was the order used in Protestant Bibles. This gave a totally new meaning to the prophets with regard to the New Testament conforming now to a History-PresentFuture chronological scheme. ${ }^{10}$

Although Luther used the Masoretic text for his German Bible of 1545, 'he also included translations of the apocryphal texts of the Old Testament - as contained in the Septuagint and the Vulgate - in his edition of the whole Bible in German' (Rasmussen 2010:144). For the translation he consulted the Septuagint and numerous rabbinic commentaries on the Hebrew text as well (cf. Rasmussen 2010:144). In the Roman Catholic Church the theological context for translating the Bible was officially finalised at Trent in 1546 consisting 'of the context of tradition, of the Church Fathers (intertextual play with Augustine, Jerome, Ambrose, Gregory the Great), [and] the word of the pope' (Rasmussen 2010:147). Luther in his conflict with Johannes Eck between the years 1518 and 1519 chose his own interpretation of scriptures. It was never important for Luther to define the limits of the biblical canon (cf. Rasmussen 2010:147). He even changed the 'canon', omitting books he disliked, like Hebrews, James, Jude and Revelations (cf. Davies 1995:64). What Luther intended with sola scriptura was his formula 'ob es Christum treibet' [whether it presents or drives at Christ] and this was linked to his way of arranging biblical books according to a 'hierarchical view of the canon' (Rasmussen 2010:147).

Luther read the traditional biblical canon in the form it had been handed down to him through medieval tradition. In this several factors played a role: his hermeneutical

9 .It is no coincidence that the Protestant reformation begins at the same time as print culture. The Protestant movements encouraged each believer to be a reader, and therefore they generated a demand for large numbers of printed texts, as did the rapidly growing urban middle class. Mass production in print culture does not only produce books, but also readers' (Aichele 2010:53).

10.Sanders (2011) remarks regarding the fact that the TaNaK is tripartite, whilst the Old or First Testament is quadri-partite: 'Structure or order determined the hermentic by which adherents read the text and is an incre part of the the hermeneutic by which adherents read the text and is an integral part of the tex itself.' Aichele (2010:45) remarks in this regard. 'A canon is a restricted and explicit intertext. The establishment of a canon is the attempt by a group of people to clarify the meaning of the included texts and to realize the narrative completeness of a text that can explain itself. The entire collection of writings becomes the proper context for reading anyone of the included texts.' principle of Law and Gospel and a promise and fulfilment scheme. In both Old and New Testament he looked for the dichotomy between what he saw as the Gospel of Christ and the Law of the Jews. According to him all biblical authors witnessed to this dichotomy and can be ordered according to a hierarchical logic. This can be seen in Luther's use of Old Testament texts. 'First of all, he returns again and again to the Psalms of David' (Rasmussen 2010:148). He also saw the Old Testament as a book of prophecy with the prophets in a central position (cf. Rasmussen 2010:149).

\section{Original Hebrew and Greek texts}

When we go back still further in history, the idea of one single canon becomes even less viable. In the medieval tradition the Greek Septuagint and the Latin Vulgate represented a form that has gradually become the standard canon in Christianity. The Masoretic text used by Jews represented a Hebrew text that was the end result of a long process of growth.

The shaping of the Hebrew canon reflects the theological and social needs of the Jews from the Babylonian captivity in the 16th century BCE to at least the meetings in Usha in the 2nd century CE' (Charlesworth 2008:63). The Christian term of 'canon' was not even in existence during the fall of Jerusalem in $70 \mathrm{CE}$. This term could not have been applied to the eventual $\mathrm{TaNaK}$ at that time, because its text was still fluid at that time. During the time of Hillel, Jesus, Johanan ben Zakkai, Josephus, and Akiba, different names were used for the Hebrew writings and there was no closed canon:

In fact, not only did the collection of books remain not-yetdefined, but the shape of many books, especially Jeremiah and the books of Samuel, appeared in widely different forms before 70. (Charlesworth 2008:64)

As indicated by Tov, more than ten different text types existed at that time (in Charlesworth 2008:64).

The eventual final forms of these different Christian Bibles were the end result of long editorial processes ${ }^{11}$ between the 5 th century BCE and the 4th century CE (cf. Schniedewind 2004:3). Over many centuries gradual decisions were made about which literature would become canonical, what the order of the books should be, the relationships amongst the books, and the editorial frameworks of the books (cf. Schniedewind 2004:3). ${ }^{12}$ According to Thomassen (2010:19) ' $[t]$ he idea of a canon in the sense of a list of accepted books first makes its appearance with Irenaeus in the 180s.' By the 4th century of our era a Christian canon was more or

11.The haunting problem of the relation between the Greek Septuagint and the Hebrew Masoretic tradition is not addressed here. Schniedewind (2004:194) is of opinion that the canon of biblical literature was largely closed by the 3rd century BCE. Students at Jewish schools in Jerusalem studied those books indicated in Ben Sirach. The translation into Greek was made by priests in the Egyptian diaspora during the mid-third century BCE. Hebrew manuscripts amongst the Dead Sea Scrolls include Hebrew manuscripts that can be dated to the 3rd century BCE. These remarks leave the problem open what the extent of the eventual Hebrew canon was during the 3rd century BCE. It was probably another form of Hebrew canon than the one(s) used for the Greek translation.

12.Ulrich (2002:37) made the interesting remark that the 'canonical process - the historical development by which the oral and written literature of Israel, Judaism, and the early church was handed on, revised, and transformed into the scriptures that we have received, as well as the processes and criteria by which the various that we have received, as well as the processes and criteria by which the various
decisions were made, - is of much more importance than the question of the form of canon.' 
less established. ${ }^{13}$ According to Aichele (2010:61) it was 'a consequence of the triumph of the orthodox "great church".' Without any doubt the desire for control was a powerful motive behind this stabilisation (cf. Thomassen 2010:19). It was inter alia intended to 'terminate the pursuit of heretical connotations of texts and readings' (Aichele 2010:61). Dominating Christian communities used the canon:

to ensure careful intertextual control of the meaning of the scriptures and to guard against the sort of unlimited semiosis that characterizes early Christian diversity, as well as contemporary post-canonical intertextuality. (p. 61)

This technological innovation of the codex was used to form a 'canon'. For the first time separate scrolls could be collected into one volume and arranged according to a specific order. This enabled the possibility of a canon concept in terms of a demarcated collection of material. In turn, this served a hermeneutical purpose. Different sections included in one volume could be easily compared with other sections and the one read in terms of the other. Aichele (2010:51) calls this 'hypertextual'. The codex enabled 'an explicit and complete intertextual network in a format that can be easily used as such' (Aichele 2010:51).

This off course indicates that there was a process of selection and collection of scrolls being copied and united into Christian codices to form a 'Bible'. It represented a specific view in Christian circles on what is canonical and what not.

In Jewish circles lists of Hebrew writings evolved into what became the Masoretic Text. From the 9th century CE Jews started to put their scriptures in codices, the earliest being the Cairo Codex. All printed Hebrew Bibles were text-critically based on these codices (cf. Davies 1995:60).

In Christian circles the Alexandrinus and Sinaiticus followed by the Vaticanus came into existence by the 4th-5th century CE. These were manuscripts of the Greek Bible containing the majority of the Septuagint and the New Testament. They differed to a lesser degree in contents, but a good deal in order. They were in fact different Bibles (cf. Davies 1995:63). Although there was a general view on what should be scripture and what should be included, there was no strict demarcated list.

It is obvious that those who collected different scrolls and handed them down to a next generation, played the major role in the forming of a canon. The meaning of the Bible is 'imbedded in the history of the people who wrote it, read it, passed it on, rewrote it, and read it again' (Schniedewind 2004:5). Several ideas about canon and canonicity taking different forms were present in the process. According to Thomassen (2010:27-28) these various ideas formed a series of stages in the eventual forming of the Christian canon:

13.Charlesworth (2008:58) chooses a late date for the finalisation of the canon. The Torah was closed first, probably before the 3rd century BCE. The books in the
Prophets came to finalisation most likely before the defeat of Bar Kochba (135/6 Prophets came to finalisation most likely before the defeat of Bar Kochba (135/6
CE). The contents of the books of Samuel and Jeremiah remained unclear until $\mathrm{CE})$. 'The contents of the books of Samuel and Jeremiah remained unclear until
at least $70 \mathrm{CE}$. Some books in the Writings were debated until the sixth century at least 70 CE. Some books in the Writings were debated until the sixth century
CE' (Charlesworth 2008:59). The finalisation of the New Testament can even be CE' (Charlesworth 2008:59). The finalisation of the New Testament can even be
extended to 1000 CE 'when the Greek Orthodox Church accepted the Revelation extended to 1000 CE 'when the Greek Orthodox Church accepted the Revelation
of John (which is still not canonical according to the Syriac Church)' (Charlesworth 2008:59).
Apostolicity, orthodoxy, tradition, revelation were present in a cumulative process. Older criteria of canonicity continued to exist alongside more recent ones, making it possible for individual believers to select various combinations of those criteria to satisfy their own needs. (Thomassen 2010:28)

In the case of apostolicity, for instance, the Christian documents were associated with Jewish scripture which already had canonical status:

[T] he writings of 'the apostles' were associated with those of 'the prophets', and the 'New Testament' was added to the 'Old Testament' to form a single Bible, in which one and the same divine voice spoke. (Thomassen 2010:25)

In association with the already established pattern of prophetically inspired scripture the apostolic writings were also seen as inspired.

However, the view that the prophetical writings were divinely inspired does not intend that they were in a fixed canonical form. Summarising his lifelong text critical study of the growth, compilation and crystallisation of the biblical canon of Hebrew scripture Talmon (2010b) rejects the traditional idea of 'one common prototype' (Talmon 2010b:418). He rather opts for a 'prudent approach' (Talmon 2010b:418) and prefers to speak of parallel traditions from which eventually a received Masoretic text evolved.

Talmon (2010a:422) concentrates on two questions:

1. 'the stimuli which set in motion the process of conjoining a cluster of ancient Hebrew writings into a compendium, which ultimately was to become the canon of Hebrew Scripture' and

2. 'the function of the biblical canon in the historical experience, and the religious thought of Israel in the early post-biblical experience.'

The transmission of history and faith-related texts, in part transmitted orally, and in part handed down in writing, was part and parcel of the Israel community from the start. Several 'authors' were involved in the process. Hypothetically there was a J, E, D, and P for the Pentateuch, the so-called Deuteronomists for Deuteronomy to Kings; First, Second, and Third Isaiah. Different people contributed to the forming of Psalms and Proverbs. There were also many unknown minor authors, redactors and scribes who contributed to the process (cf. Ulrich 2002:32). This process as 'societal phenomenon' (Talmon 2010a:422) was deeply affected by historical events and religious developments. Literature and life were linked closely together, so that literary tradition and the closure of the 'Hebrew Canon of Scripture' (Talmon 2010a:423) 'constituted the corporate biography of biblical Israel' (Talmon 2010a:423).

Next to Israel other communities (like the Qumranites and Christians) also embraced the Hebrew Bible as (part of) the foundation document of their respective faiths. From:

the last centuries $\mathrm{BCE}$ onwards the varying composition of the biblical canon became signposts of the diverse communities that embraced the Hebrew Bible as a foundation document of their discrete faiths. (Talmon 2010a:425-426) 
This led to a diversity of canons. In Israel the corpus functioned as 'a touchstone for identifying all those who adhered to it as bona fide members of the community, and all others as excluded outsiders' (Talmon 2010a:428).

With regard to 'the crystallization of a biblical canon', Talmon (2010a:428) found that there were no formal decisions of authoritative institutions that regulated the establishment of a corpus of authoritative writings. It was rather the vox populi, the public acclaim and popularity of the books that caused them to become part of a larger compendium. It is this 'absence of any supervising agency or agencies which may explain the exceeding diversity of literary genres, linguistic competence, and religious significance, which marks the books accumulated in the compendium' (Talmon 2010a:429). The later Jews 'did not consider their assemblage of biblical writings a closed canon of the Holy Writ' (Talmon 2010a:433). It was an open-ended biblical canon in which there was room for variant wordings and different orders. Talmon (2010a:434) terms this 'the living Bible'. There is not any sign here of a 'demarcated and precisely defined closed corpus of textually fixed or at least stable literary works, to which nothing can be added, and from which nothing can be detracted' (Talmon 2010a:435-436).

Ryle and Buhl's theory of a synod at Jamnia or Jabneh is also refuted. There is no proof that in the Second Temple era or in the period following the Roman capture of Jerusalem, neither in the Apocrypha nor in any Hellenistic writings any statement can be found of an 'academy', a 'synod', or any other official body that decided on the inclusion of a book amongst the 'holy writings' or decreed the 'canonization' of the corpus (cf. Talmon 2010a:436). Talmon (2010a:436) states categorically that the hypothesis of a 'Synod of JabnehJamnia is absolutely untenable.'

On the other hand the concept of canon defines a fixed corpus of literature to which nothing can be added, and from which nothing can be removed. There was 'a conscious, retrospective, official judgment' (Ulrich 2002:37) that confirmed what had gradually become a circumscribed collection of books for future generations. In this context " $[a]$ "canon" is thus by definition a way of setting limits to the books recognized as holy' (Talmon 2010a:437). It represents the sages' conviction that the biblical era had come to an end. This eventually led to the insistence on a clear-cut differentiation between the closed Bible canon and the later literature of the sages and the oral law (cf. Talmon 2010a:438). ${ }^{14}$

Many of the books eventually included in the final Hebrew collection were still in a 'state of creative development until at least 70 C.E. and possibly as late as 132' (Ulrich 2002:32). ${ }^{15}$ In the late first and the beginning of the 2nd century $\mathrm{CE}$ socio-religious disintegration went hand in hand with 14. Uirich (2002:32) refers to this stage as 'reflective judgment'.

15.Ulrich (2002:32) remarks that when the books of the period of the late Second Temple are considered 'we must distinguish between the book or literary opus and the particular wording or literary edition of that opus', 'It was the book, i. the particular wording or literary edition of that opus." "It was the book, i.e., the scroll, not its particular wording or literary edition, which made the hands unclean according to the rabbis' (Ulrich 2002:32). In this context the phrase "hands unclean' equals the term 'canon'. the destruction of external forces, and diverse separate communities arose. Talmon (2010a:410) calls this the 'Great Divide'. Talmon (2010a:410-411) states that ' $t$ ] his centrifugal challenge was countered with a centripetal response by Judaism to keep everything integrated. This led to the crystallization of a clearly circumscribed and fixed canon of Scripture.'

From this historic overview it is clear that there never was and never will be just one form of the canon. Parallel passages in the Hebrew Masoretic Text and other ancient versions indicate that there were other traditions as well. Critical editions, such as the Hebrew University Bible (HUB), the Biblia Hebraica Stuttgartensia (BHS), the Biblia Hebraica Quinta (BHQ), and the Biblia Qumranica (cf. Talmon 2010a:418), show this clearly. To refer to 'the' canon is naïve and ignores the history of the forming of the canon as well as the factual use of a canon. On the other hand there is enough common ground between these variations to identify a kernel of a biblical canon. One should therefore state clearly what one intends by 'canon' and what the extent and the order of the books are in the canon one is working with. To which canon is one referring when one uses the term 'canon'? This brings us to the question of how a canon can be used, when the focus is not on a specific form of the canon, but rather on the contents.

\section{An Emic and an Etic approach}

Davies (1995) used the anthropological terms 'emic' and 'etic' to distinguish between two contexts for a general critical reading strategy of biblical literature (cf. Davies 1995:11). From an 'emic' perspective the history and use of the specific canon one uses, is studied. From an 'etic' perspective one can investigate 'how various Christian and Jewish canons have developed and functioned within the respective communities' (Davies 1995:35). The emic perspective reads 'inside the canon' (Davies 1995:11), and equals biblical literature with scripture, with the aim to 'understand more fully its historical, ideological, rhetorical or religious character to enhance the function of the literature as scripture' (Davies 1995:12). The etic perspective on the other hand operates 'outside' the canon and regards:

the collection and transmission of the contents as part of the reception history of a literature which was created, and given various kinds of authority through time, by the actions of humans, and that these acts of writing and reception are to be evaluated on the same terms as other human acts of writing and reception, just as Jewish and Christian canons are put on an equal footing with other canons of world religions. (Davies 1995:12)

The emic discourse is confessional and concerned with only one canon functioning 'authoritatively and normatively' (Davies 1995:34). The etic approach is non-confessional and gives an external description of the phenomenon of canon whether it is in the form of the Bible, the Qur'an, the Book of Mormon or the Gathas. 
When Davies (1995:16) tries to 'apply the principles of a selfconsciously non-confessional discourse' in reading the Bible, he states that the emic and etic discourse are fundamentally quite different from each other and imply two different kinds of discourses with regard to biblical issues (cf. Davies 1995:13).

However, when we choose to read the Bible emically in Davies's terms, that is, from a confessional perspective only, we have to keep in mind our exploration of the history of canon above. I beg to differ from Davies in this regard. These different forms of the canon represent a variety of traditions. Although these are different approaches, the Bible should be read from both an emic as well as etic perspective. Even when we read the biblical canon from only an emical perspective, it is not sufficient to pay attention to its historical, ideological, rhetorical or religious character (cf. Davies 1995:12) only. The Protestant principle that the Bible is simultaneously the Word of God and word of men compels us to pay attention to the way literature is created as well, its reception history, and the way authority was conferred upon it through time by the actions of humans. The borders of canon were permeated by so many groups under so many different circumstances that it is no longer possible to speak of 'the' one single canon. We only have different forms of the same Bible. To understand this phenomenon we shall have to study the canon from an emic as well as an etic perspective. Different aspects can be studied from these two advantage points.

In the history of canonical criticism Childs $^{16}$ gave priority to the shape of the biblical canon. He saw the biblical canon as norma normata for faith. On the other hand Sanders chose for the process of canon forming the main object as being canon criticism. In essence, his approach gives attention to both the emic as well as the etic aspects of canon. Sanders (1991:92) agrees that there is a 'hermeneutical shape to the Jewish and Christian canons'. However, this shape is driven by the thrust of 'theocentric monotheizing pluralism' (Sanders 1991:92). At the back of the process of forming a canon to function as norma normans there was always 'the unrecorded hermeneutics that lie amongst all the pages of Scripture, and ... this canonical hermeneutic derives from Scripture's basic intertextual nature' (Sanders 1991:92). What is needed therefore is a study of intertextuality within the context of a canon.

\section{Intertextuality}

Aichele (2010) addressed the problem of the ideological aspect of forming a canon. This is a factor that played a role right from the beginning up to today. Ideological forces have been driving the forming of a canon from the beginning, and are still controlling the use of a canon. An existing text is 'recycled' by the reader by understanding the text in relation to him or herself and their community. The reader and the community are always informed by an ideology - that is, a faith or system of beliefs. In this way an intertextual network is formed between text and the situation in which the readers are situated (cf. Aichele 2010:64).

16.Childs used the term 'shape' in his publications (cf. Childs 2002)
Even within the canonical text itself an 'intertext' can be formed by using a so-called canon within the canon. Each individual text of the canon does not carry equal weight, because the intertextual formula acts as norm to discriminate between texts. This process of intertextuality then 'controls which texts are legitimately to be considered as authoritative scripture, sanctioning authoritative intertexts to the reading and interpretation of each of the texts incorporated within it' (Lundhaug 2010:70). The concept of intertextuality in its reader-centred form 'can therefore be a useful tool for conceptualizing the functions of a canon' (Lundhaug 2010:71). Intertextuality is located in the reader's mind from where it activates a dialogical interplay between reader and texts and between two or more texts. In this way intertextuality can create a heuristic pattern for understanding and interpreting the Bible.

I indicated elsewhere (Venter 1997:327-333, 2009:158-159) that the study of intertextuality usually focuses on two aspects of the process: those of aesthetical production and of polylogy. In aesthetical intertextuality the production of texts takes place when existing literature is used to form new texts. Existing texts are quoted or combined with a new set of words into new texts. Here selection (paradigmatic use of words) as well as a combination (syntagmatic use of words) is found. This can take many forms: 'quotation, paraphrase, résumé, commentary, criticism, interpretation, allusion, parody and even pastiche' (Venter 2009:159). Intertextuality is always present either obviously linking a new text to other existing texts, or symptomatic where the relationship is still visible, although no direct indications are present.

For the second aspect of polylogy Julia Kristeva's term 'intertextualité' can be used. According to Kristeva's theory every 'text' is influenced by a multiplicity of 'texts' and by several ideas which are either re-read, condensed, replaced or deepened into a new form. Codification of the social system takes place by using language, relevant contents and structuring those contents and presenting them in a document. The reader creatively forms a new combination of elements by 'hypo-codifying' (a term coined by Umberto Eco) the texts he or she consulted into a new codification. This deconstructionist exercise is the result of the dialogistic aspect of speech act (cf. Venter 2009:159).

Both of these aspects, indicated above, were present during the process of forming a biblical canon. ${ }^{17}$ I proposed (Venter 2002:470-488) that three interacting levels can be identified in the process of forming a canon. These three levels are those of the history of a separate book, the collection of material, and the socio-historic context in which the process takes place.

The final form of the Masoretic Bible is an example of how the collection of material took place. In its present published form (BHK, BHS, Quinta) it is a compilation of 22 books.

17. Cf. Aichele's interesting remark that a canon invites a dynamic process. Aichele (2010:45) said that the 'canon of scripture is a hypertextual machine that supports the continual and creative recycling of the Bible. The potential to combine texts through seemingly endless permutations and reconfigurations of the multi-textua collection is one of the great strengths of the biblical canon. The canon opens a semiotic space within which creative interpretation of biblical texts is encouraged.' 
Each of these books represents a history of its own, ranging from original oral traditions to a final written text. The Dead Sea Scrolls revealed that there were stages in which 'the text of the separate books of scripture was pluriform and still creatively developing, prior to the period of a single text for each book' (Ulrich 2002:31). Each of these books is the layered end result of a dialogical cognitive 'process in which each new phase of its literary growth was undertaken in dialogue' (Venter 2002:472) with the existing form(s) of that unit and in dialogue with the context of the people who handed it down. ${ }^{18}$ This process of 'dialogical compaction' (Venter 2009:158) can be studied in terms of 'aesthetic intertextuality' (cf. Venter 2009:158-159). As will be indicated below the theories of Fishbane (1985) and Fisk (2001), are quite helpful in this regard.

Secondly, the selection and combination of these books into an eventual fixed and final form can be attributed to the ideological decision of one or other group. It represents their view of what can be deemed as authoritative and what not. This process took place in interaction with other groups that compiled their own final collection and the collections they decided upon. This indicates an aesthetic as well as a polylogic intertextual process of dialogue between different theological opinions found in the traditional texts and the viewpoints of religious peer groups (cf. Venter 2002:472 for this argument).

Thirdly, dialogue and intertextuality with the tradition of the books and the decision on the books to be collected, took place in a socio-historical context. The following factors played a very large role in the forming of a specific canon: revision of the tradition, additions to it, omissions of material, compilation of different books and editing the final collection. This happened to comply with a large array of social factors. Here the aspect of 'polylogic intertextuality' (Venter 2009:158) was dominant.

These three levels which I indicated as being a 'dialogical composite cognitive process' (Venter 2009:158), an 'ideological choice' (Venter 2009:158) and dialogue with the socio-historical context (cf. Venter 2002:472) in which both aspects of intertextual aesthetical production and polylogy played a role, can now be applied to the phenomenon of canonicity.

The forming of a canon as well as the use of a fixed canon was always a dynamic process. It was acknowledged in the 19th century already that the textual versions of the Septuagint, Targum and Samaritan Pentateuch were translations of one or other form of Hebrew Bible available to the translators. They did their work within the context of specific social and theological concerns. What is even more, it was acknowledged that the eventual Hebrew Bible itself is the product of reworking (cf. Fishbane 1985:5). ${ }^{19}$ In the composite Hebrew Bible internal strata can be identified. The text cannot be read

18.For this argument see Venter (2002:472).

19.For a fuller discussion of Fishbane and Fisk see Venter (2009:159-160). on a single level, because it is the layered end result of a long process in which interpretation and exegesis played a role. Fishbane (1985) used the terms traditum [(inherited tradition] and traditio [literary transformation] to study this process. Traditum is used to indicate the end result of this long and varied process of transmission. When this received traditum is interpreted, this process is called traditio (cf. Fishbane 1985:6). Once the traditio was fixed and became a standardised text as traditum, it led to new interpretations again called traditio. This process is inherent to the biblical text itself. As fixed canon it always induces new interpretations. This phenomenon of reworking and supplementing original authoritative texts is found in Judaism, Christianity and Islam.

Whilst Fishbane (1985) focused on the inner-biblical flow from traditum to traditio, Fisk (2001) focused on the re-use of the already coagulated traditum in extra-biblical material. Fisk (2001:67-68) proposed that there is a substantial and organic continuity between the earlier exegesis already found in the Bible and the later rabbinic strategies of interpreting scripture. This type of exegesis can also be found in the Bible itself, in Samuel-Kings as well as in the work of the Chronicler. It was continued in extra-biblical material in what Vermez (1975:62) coined 'rewritten Bible', or 'para-biblical writings' (TrebolleBarrera 2000:102). It can be found in books like Jubilees, the Genesis Apocryphon (1QapGen), 1 Esdras, Josephus's Antiquities and Liber Antiquitatum Biblicarum.

Fisk (cf. 2001:109-110) paid attention to two aspects of this on-going process of re-using the traditum: the compositional techniques (the mechanics of a citation or allusion to scripture) and the hermeneutical strategy (the hermeneutical function of the precursor text within the new context and within the social-historical setting that gave rise to the new composition). Fisk (2001:118-126) developed a model to indicate the relationship between traditum and traditio. $\mathrm{He}$ indicated that a large variety of factors contributed to the gravitational pull from traditum to traditio. It could take any of four directions. The focus can fall on either the traditum or the traditio. 'The transformation from traditum into traditio can be either static (receptionist) or dynamic (innovative)' (Venter 2009:160). When dynamic traditio is in the foreground either free use can be made of the traditum or the traditum can be negated. When a static traditum is in the foreground the traditum can either be explicated or transformed. Within these four quadrants 'we might plot virtually any instance of inner-biblical exegesis, intertextual echo and midrashic reading' (Fisk 2001:118). Several external factors also contributed to this dynamic process, such as politics, culture and history. Fisk (2001:127) refers to 'general patterns of interaction between exegesis and social context.' Because the social context of exegesis is not also known, it seems to me better to rather deduce a pattern or type of interaction found in the text itself.

\section{The Book of Jubilees}

We can apply these theories to literature that obviously used older materials represented in present-day canons. In that 
literature the existing materials were dynamically made into new traditio.

The Book of Jubilees ${ }^{20}$ is 'rewritten Bible' (Vermez 1975), or a 'para-biblical writing' (Trebolle-Barrera 2000). Wintermute (1988:39) described Jubilees 'as a Midrashic reflection on Exodus 24:18'. It overlaps with the materials in Genesis to Exodus 19. The available text(s) of Genesis and Exodus were used as basis and complemented with some other contemporary materials. Jubilees has a homiletically character, paying careful attention to the text, and adapted to contemporary circumstances. Different techniques were used, 'such as choosing key points, omission, transformation, halakhic interpolations, addition of material, condensing freely, expurgating, explaining, supplementing and sometimes radically recasting the biblical episodes' (Venter 2008:631; cf. also Wintermute 1988:35). In this way a particular understanding of the original document was presented. The author(s) made several additions to the biblical text where it lacks sufficient detail to serve the author's concern, especially with regard to the sacred calendar (cf. Endres 1987:221). Wintermute (1988:37) is of opinion that these additions consisted of 'a considerable amount of traditional material which came to him in either written or oral form.' Wintermute (1988:40) could not establish which original extra material was used, but is sure that the author(s) of Jubilees had 'an extensive knowledge of Scripture which enables him to bring to bear widely scattered biblical texts in his discussion of a problem.'

A probable profile of the author(s) can be drawn when the book is studied on an intertextual level. She or he belonged to a group who served priestly and pedagogical concerns. The idea of retribution was very prominent amongst the members. An apocalyptic viewpoint is found all through the book. There was some type of crisis, namely: which calendar was to be followed in the cult in her time. Mixed marriages were also of great concern to her. The viewpoint on these was used to formulate what it meant to be holy. This viewpoint existed independently and parallel to other contemporary traditions. Along with these alternative views on calendar and marriage, large influence was exerted on the Essene-Qumran community. The nationalism of the book and the effort to continue the Moses tradition combined with an apocalyptic viewpoint put him or them near the central stream of Judaism.

According to Vermes (1975:62) three types of applied exegesis can be indicated in the Book of Jubilees: 'fulfilmentinterpretation,' 'pure exegesis' and application of geographical terms. According to Endres (1987:221) these changes can help to characterise the time in which the book was written.

20.When Charlesworth investigates the meanings that 'apocrypha' and 'pseudepigrapha' can have for canonical studies, he states that ' $[t]$ hese numerous
and sometimes lengthy and beautiful works helped shape the canon and mirror and sometimes lengthy and beautiful works helped shape the canon and mirror
the process ...' (Charlesworth 2008:57). For Charlesworth (2008:67) these the process ...' 'Charlesworth 2008:57). For Charlesworth (2008:67) these
documents are 'paradigmatically important' because they give 'information of documents are paradigmatically important ' because they give 'information of the life in anters and the earliest writings of the New Testament (1 Thessalonians - c.a. 50 C.E.), and they reflect major historical events during this time.' These texts can be very helpful to understand the forming of the eventual biblical canon.
An example of the way in which existing traditum was used to form new traditio in Jubilees can be found in the exceptionally layered text of Jubilees 23:8-32. In this chapter the report on Abraham's death in Genesis 25:7-11 is used to present a viewpoint on 'the theological meaning of Israel's history between creation and Moses' receiving of the law at Sinai' (Venter 2007:479). History is interpreted in terms of a heptadic jubilee system..$^{21}$ In this scheme 'everything is ordered according to the directions of the law on Sabbaths and festival days' (Venter 2007:479). In Psalm 90 longevity is understood in terms of declining followed by inclining in human age. It is also interpreted according to the traditional Deuteronomistic retributive scheme of sin-punishmentrepentance-salvation. Finally the author superimposed an eschatological-apocalyptic expectation on this intertextual creation. It is expected that in the last days everybody will be obey the law of God.

In the biblical source text (the present Gn 25:1-6) the narrative of Abraham's marriage to Keturah is directly followed by a report on Abraham's death and his burial (Gn 25:7-11). Then there follows a list of Ishmael's descendants (Gn 25:12-18). In the Book of Jubilees the first narrative on Abraham and Keturah and the third story on Ishmael's offspring are left out. After reporting on Abraham's death (Jub 23:1-7= Gn 25:7-11) a new section follows on the general decline in longevity (Jub 23:8-32). The Genesis text does not give any information on this decline. However, the information in Genesis 25:7-8 that Abraham lived a total of 175 years is reflected in Jubilees 23:9 and 23:27. Here totally different numbers and units are used: three jubilees and four weeks of years. The Book of Jubilees uses heptadic units of seven week years. Three jubilees are $3 \times 49=147$ years. Four weeks of years is $4 \times 7=28$ years. Added together this is the equivalent of the 175 years in Genesis text (cf. Venter 2007:469). In Jubilees the significant events in Israel's history, outlined in Genesis and Exodus, are calculated according to a 49-year scheme. This scheme works with the units of 'jubilees', 'week years' and 'years'. This chronological scheme was inter alia 'used to indicate that the past is orderly and calculable because it has been arranged by God' (Venter 2007:470) - from this follows that the future can also be calculated. One can therefore know where you fit into the divine plan of history (cf. VanderKam 2000:177-178).

Next to re-calculating history with the use of a heptadic scheme, Jubilees used Psalm $90^{22}$ to indicate a decreasing tendency in man's lifespan, followed by a future incline. At the start of the unit (23:9) and at the end (23:27), reference is made to a long life of 19 jubilees of years (931 years). However, Abraham's death at the relative short age of 'a jubilee and a half' (Jub 23:15 = 175 years) presented a problem to the

21.The Jubilee system of sabbatical weeks and jubilees is based on the priestly creation story in Genesis 1 . The command to keep the Sabbath in the Covenant Code (Ex 23:10-11) also played a role as well as 'the more extended sabbatical prescriptions in the Holiness Code (Lv 25:2-7), and the seventh year rules in the Deuteronomic Code (Dt 15:1-11)' (Venter 2007:469). The sabbatical year is also linked to Israel's history in Leviticus 26:34-35 (cf. VanderKam 2000:169).

22.Jubilees refers to the poem we today know as Psalm 90 . This does not mean that at that time the Psalm was part of a final book of psalms as we know it today. The 'Psalter as we learn from a study of the Qumran Psalter was not yet closed and the 'Psalter as we learn from a study of the Qumran Psalter was not yet closed and the
order of the psalms not yet established during the time of Jesus' (Charlesworth 2008:62). 
author. To solve the problem the author referred to Psalm 90:10: 'The days of our life are seventy years, or perhaps eighty, if we are strong; even then their span is only toil and trouble.' Extending on the 'toil and trouble' in Psalm 90, the author of Jubilees links his idea of a time with no peace to the idea found in Psalm 90 that the brevity of life is to be understood in terms of God's wrath. Therefore Abraham shared in the Mitschuld [shared guilt] of his people. There was no way in which he could escape from God's judgement on human sin. In the heading of Psalm 90 Moses is indicated as the author. According to the Book of Jubilees it is revealed to Moses $^{23}$ that God's wrath is manifested in the brevity of life. However, in future people will start to live longer. A slow increase will occur in longevity until it approaches a thousand years (Jub 23:27) again. A parabolic line is formed in longevity (cf. Venter 2007:473).

This scheme of decline-incline fits in with the next scheme the author used. Jubilees 23:16-31 is structured according to a 'Deuteronomistic Patterning' (Endres 1987:53). This often-used scheme, found in Deuteronomy 31-34 (especially in Deuteronomy 32:1-43), takes the form of a retributive historical schema. It consists of the consecutive elements of sin, punishment, penitence and salvation. Jubilees 23:1631 is divided into the following sections: $\sin (23: 16-21)$, punishment (23:22-25), penitence (23:26), and salvation (23:27-31). This scheme is imposed upon the events between creation and new creation described in the book. The heptadic history is also interpreted in terms of the covenantal stipulations of retribution.

This scheme enables the author to end off on an eschatological note when redemption will take place. Jubilees 23:8-32 presents an eschatological perspective. In the final stage, the 'end time' people will start to obey the law. Their days will begin to increase and they will live longer (Jub 23:27), even approaching a thousand years (Jub 23:27). The eschatological poem in Jubilees 23:24-31, probably inserted in the prose section of Jubilees $22-23$ by a redactor (cf. Davenport 1971:342), uses typical eschatological ideas to sketch a wonderful time when all suffering will be replaced by peace. The author presented an eschatological vision for the community of his time in which he:

skilfully combined illusions to the contemporary situation of tension caused by the temptations to assimilation in Palestine, with a vision of the future outcome of the struggle between those who remain faithful and those who do not. (Endres 1987:201)

We can no longer identify all the sources used by the author(s). Neither can we any longer indicate correctly which form of the scriptures she or he used. Something can be seen by the techniques he used and the purpose(s) he had in mind. Only 'general patterns of interaction between exegesis and social context' (Fisk 2001:127) can be indicated. One of the primary goals of Jubilees was 'to make the ancient text speaks [sic] more directly to contemporary concerns' (VanderKam 2001:93). Living in a time of crisis and in conflict with the 23.The Book of Jubilees pretends to have been dictated to Moses in its entirety (cf. Jub 1:1-6). established priestly corps, she or he interpreted the traditums available to analyse the contemporary situation. A heptadicretributional-eschatologic heuristic scheme is used to help the hearers to survive in a time of infliction.

\section{Conclusion}

It is not viable to refer to 'the' biblical canon as if it exists in only one single form. Not only do the published versions of the Christian Bible differ from each other in extent and order, but variation can also be indicated in the Hebrew and Greek texts used for these translations. Both of these were the results of very long editorial processes in which a wide variety of forms eventually developed into a few standard parallel forms.

The dynamic processes that drove this development should be studied from both an emic as well as an etic approach. There is not only a confessional aspect, but also an aspect of human literature present in the forming of a biblical canon. The concept of intertextuality provides a useful tool to study canonicity. Not only aesthetical and polylogic inner-Bible textuality can be explored in scriptures, but also a continuous dialogue with older traditions, other religious groups and contemporary circumstances.

The movement between traditum and traditio was not only present in the forming of a biblical canon, but also in the use and reuse of this growing compilation of material. The pseudepigraphical book of Jubilees gives an indication of a dynamic explication of the way the traditum of the 2nd century BCE was explored to continue the Moses tradition under a new set of circumstances. In Jubilees 23:8-32 different sections still found in modern Bibles were used to interpret Abraham's life. The lifespan of Abraham is recalculated using a heptadic scheme. The comparative brevity of his life is explained in terms of the contents of Psalm 90. A 'Deuteronomistic Patterning' (Endres 1987:53) is superimposed on a theory of longevity giving the opportunity to project an eschatological expectation on the future when an idyllic time of peace will arrive.

Here the traditum - or what can be indicated as the 'canon' of the day - was used not in terms of a demarcated collection of authoritative sayings, but as a model on which contemporary theologising is based. The case is clear that some type of 'canon' existed. However, it is explored in terms of theological viewpoints. The boundaries here are not scriptural boundaries linked to two hard covers on the outside, but to those of the ideas and theological tradition. This shows the way for people who are disillusioned with the idea that a canon is restricted to a certain quantity of pages and who can find a new way of using a canon as guideline rather than a corpus of fixed dogmata.

\section{Acknowledgements}

This article is dedicated to the Dean of the Faculty Theology at the University of Pretoria, Prof. Johan Buitendag, the 
Deputy Dean, Prof. Dirk Human, and all the staff members of the Faculty where I spent 28 stimulating and fulfilling years of my life between 1984 and 2012.

The research for this article has been performed with the support of the National Research Foundation of South Africa.

\section{Competing interests}

The author declares that he has no financial or personal relationship(s) which may have inappropriately influenced him in writing this article.

\section{References}

Aichele, G., 2010, 'Canon, ideology, and the emergence of an imperial church', in E. Thomassen (ed.), Canon and canonicity: The formation and use of Scripture, pp. 45-65, Museum Tusculanum Press, Copenhagen.

Charlesworth, J.H., 2008, 'Writing ostensibly outside the Canon', in C.A. Evans \& E. Tov (eds.), Exploring the origins of the Bible, canon formation in historical, literary, and Theological perspective, pp. 57-85, Baker Academic, Grand Rapids, MI.

Childs, B.S., 2002, Biblical Theology: A proposal, Augsburg Fortress Publishing, Minneapolis, MN.

Davenport, G.L., 1971, The eschatology of the Book of Jubilees, Brill, Leiden.

Davies, P.R., 1995, 'Whose Bible is it anyway?', Journal for the Study of the Old Testament, suppl. ser.

Endres, J.C., 1987, Biblical interpretation in the Book of Jubilees, Catholic Biblical Association of America, Washington, DC. (The Catholic Biblical Quarterly Monograph Series, 18).

Fishbane, M., 1985, Biblical interpretation in ancient Israel, Clarendon, Oxford.

Fisk, B.N., 2001, 'Do you not remember? Scripture, story and exegesis in the rewritten Bible of Pseudo-Philo', Journal for the Study of the Pseudepigrapha, suppl. ser. 37.

Halpern-Amaru, B., 1994, Rewriting the Bible: Land and covenant in post-biblical Jewish literature, Trinity Press International, Valley Forge, PA.

Lundhaug, H., 2010, 'Canon and Interpretation: A cognitive perspective', in E. Thomassen (ed.), Canon and canonicity. The formation and use of Scripture, pp. 67-90, Museum Tusculanum Press, Copenhagen.

Rasmussen, T., 2010, 'The biblical canon of Lutheran reformation', in E. Thomassen (ed.), Canon and canonicity. The formation and use of Scripture, pp. 143-158, Museum Tusculanum Press, Copenhagen.

Sanders, J.A., 1991, 'Canon as shape and function', in J. Reuman (ed.), Promise and practice of biblical Theology, pp. 87-97, Fortress Press, Minneapolis.
Sanders, J.A., 2011, 'Review of Text and canon of the Hebrew Bible, by S. Talmon', Review of Biblical Literature 4, viewed 26 July 2013, from http://www. bookreviews.org/pdf/7848_8620.pdf

Schniedewind, W.M., 2004, How the Bible became a book: The textualization of Ancient Israel, University Press, Cambridge. http://dx.doi.org/10.1017/ CBO9780511499135

Talmon, S., 2010a, 'The crystallization of the "Canon of Hebrew Scriptures" in the light of biblical scrolls from Qumran', in S. Talmon (ed.), Text and canon of the Hebrew Bible: Collected studies, pp. 419-442, Eisenbrauns, Winona Lake, IN.

Talmon, S., 2010b, 'Textual criticism: The ancient versions', in S. Talmon (ed.), Text and canon of the Hebrew Bible: Collected Studies, pp. 383-418, Eisenbrauns, Winona Lake, IN.

Thomassen, E., 2010, 'Some notes on the development of Christian ideas about a canon', in E. Thomassen (ed.), Canon and canonicity: The formation and use of Scripture, pp. 9-28, Museum Tusculanum Press, Copenhagen.

Trebolle-Barrera, J., 2000, 'Qumran evidence for a biblical standard text and for nonstandard and parabiblical texts', in T.H. Lim (ed.), The Dead Sea Scrolls in their historical context, pp. 89-106, T\&T Clark, Edinburgh.

Ulrich, E., 2002, 'The notion and definition of canon', in L. M. McDonald \& J.A Sanders (eds.), The canon debate, pp. 21-35, Hendrickson Publishers, Peabody, MA, viewed 26 July 2013, from http://www.amazon.com/The-Canon-Debate-MartinMcDonald/dp/0801047080

VanderKam, J.C., 2000, 'Sabbatical chronologies in the Dead Sea scrolls and related literature', in T.H. Lim (ed.), The Dead Sea scrolls in their historical context, pp. 159-178, T\&T Clark, Edinburgh.

VanderKam, J.C., 2001, The Book of Jubilees, Sheffield Academic Press, Sheffield.

Venter, P.M., 1997, 'Intertekstualiteit, kontekstualiteit en Daniël 9', In die Skriflig/In Luce Verbi 31(4), 327-346. http://dx.doi.org/10.4102/ids.v31i4.1618

Venter, P.M., 2002, 'The connection between wisdom literature, apocalypses and canon', Old Testament Essays 15(2), 470-488.

Venter, P.M., 2007, 'Intertextuality in the Book of Jubilees', HTS Teologiese Studies/ Theological Studies 63(2), 463-480. http://dx.doi.org/10.4102/hts.v63i2.213

Venter, P.M., 2008, 'Space, time and group identity in Jubilees 8-9', HTS Teologiese Studies/Theological Studies 64(1), 631-650. http://dx.doi.org/10.4102/hts. v64i1.62

Venter, P.M., 2009, 'Canon, intertextuality and history in Nehemiah 7:72b-10:40', HTS Teologiese Studies/Theological Studies 65(1), Art. \#135, 8 pages. http://dx.doi. org/10.4102/hts.v65i1.135

Venter, P.M., 2010, 'A triadic construct in Jubilees 30', HTS Teologiese Studies/ Theological Studies 66(1), Art. \#801, 8 pages. http://dx.doi.org/10.4102/hts. v66i1.801

Vermes, G., 1975, Post-biblical Jewish studies, Brill, Leiden.

Wintermute, O.S., 1988, 'Jubilees (2nd Century BC): A new translation and introduction', in J.H. Charlesworth (ed.), The Old Testament pseudepigrapha: Expansions of the 'Old Testament' and legends, wisdom and philosophicalliterature, prayers, psalms, and odes, fragments of lost Judeo-Hellenisticworks, vol. 2, pp. 35-142, Doubleday, New York. 